Provided for non-commercial research and education use. Not for reproduction, distribution or commercial use.

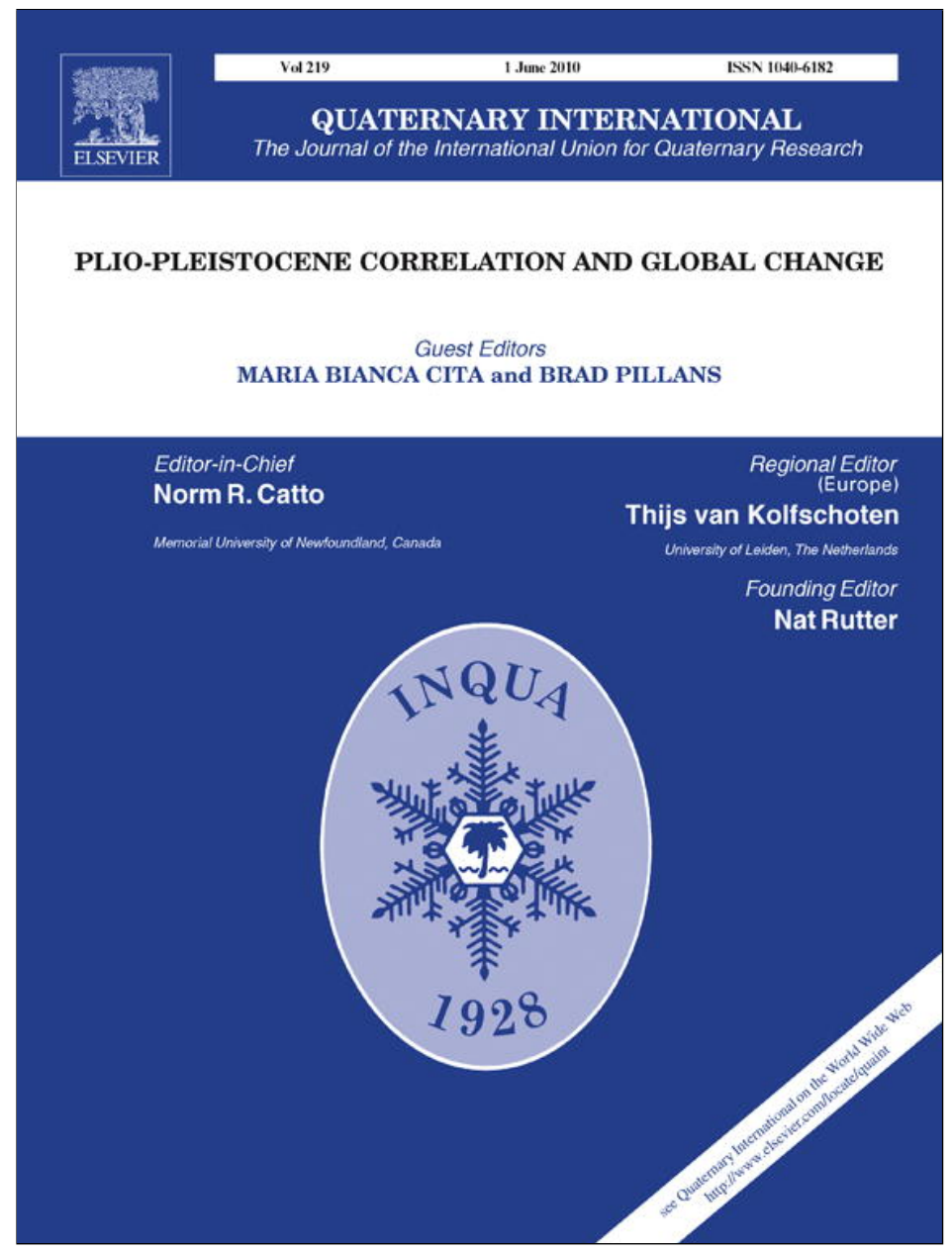

This article appeared in a journal published by Elsevier. The attached copy is furnished to the author for internal non-commercial research and education use, including for instruction at the authors institution and sharing with colleagues.

Other uses, including reproduction and distribution, or selling or licensing copies, or posting to personal, institutional or third party websites are prohibited.

In most cases authors are permitted to post their version of the article (e.g. in Word or Tex form) to their personal website or institutional repository. Authors requiring further information regarding Elsevier's archiving and manuscript policies are encouraged to visit:

http://www.elsevier.com/copyright 


\title{
Plio-Pleistocene trends in ice rafted debris on the Lomonosov Ridge
}

\author{
Matthew O'Regan ${ }^{\mathrm{a}, *}$, Kristen St. John ${ }^{\mathrm{b}}$, Kathryn Moran ${ }^{\mathrm{a}}$, Jan Backman ${ }^{\mathrm{c}}$, John King ${ }^{\mathrm{a}}$, \\ Brian A. Haley ${ }^{\mathrm{d}}$, Martin Jakobsson ${ }^{\mathrm{c}}$, Martin Frank ${ }^{\mathrm{d}}$, Ursula Röhl ${ }^{\mathrm{e}}$ \\ ${ }^{a}$ Graduate School of Oceanography and Department of Ocean Engineering, University of Rhode Island, Narragansett, Rhode Island, USA \\ ${ }^{\mathrm{b}}$ Department of Geology and Environmental Science, James Madison University, Harrisonburg, Virginia, USA \\ ${ }^{\mathrm{c}}$ Department of Geology and Geochemistry, Stockholm University, Stockholm, Sweden \\ d IFM-GEOMAR, Leibniz Institute of Marine Sciences, Kiel, Germany \\ e Center for Marine Environmental Sciences, Bremen University, Bremen, Germany
}

\section{A R T I C L E I N F O}

Article history:

Available online 18 August 2009

\begin{abstract}
A B S T R A C T
Although more than 700 sediment cores exist from the Arctic Ocean, the Plio-Pleistocene evolution of the basin and its marginal seas remains virtually unknown. This is largely due the shallow penetration of most of these records, and difficulties associated with deriving chronologies for the recovered material. The Integrated Ocean Drilling Program's (IODP) Expedition 302 (Arctic Coring Expedition, ACEX) recovered $197 \mathrm{~m}$ of Neogene/Quaternary sediment from the circumpolar regions of the Lomonosov Ridge. As detailed analyses of this material emerge, research is beginning to formulate a long-term picture of paleoceanographic changes in the central Arctic Ocean. This paper reviews the ACEX PlioPleistocene age model, identifies uncertainties, and addresses ways in which these may be eliminated. Within the established stratigraphic framework, a notable reduction in the abundance of ice rafted debris (IRD) occurs in the early part of the Pleistocene and persists until Marine Isotope Stage 6 (MIS 6). Therefore, while global oceanographic proxies indicate the gradual growth of terrestrial ice-sheets during this time, IRD delivery to the central Arctic Ocean remained comparatively low and stable. Within the resolution of existing data, the Pleistocene reduction in IRD is synchronous with predicted changes in both the inflow of North Atlantic and Pacific waters, which in modern times are known to exert a strong influence on sea ice stability.
\end{abstract}

(c) 2009 Elsevier Ltd and INQUA. All rights reserved.

\section{Introduction}

A record of Plio-Pleistocene environmental change in the Arctic Ocean is a key piece missing from global climate reconstructions. Of paramount interest are variations in the form, intensity and permanence of sea ice cover, which have a profound impact on the earth's albedo and global thermohaline circulation (Thiede, 1991; Aagaard and Carmack, 1994). Observational records and modeling results highlight the strong interplay between hydrologic processes in the Arctic Ocean, namely changes in the freshwater budget, and exchange with both the Pacific and Atlantic Oceans, emphasizing their role as primary controls on modern sea ice stability (Steele and Boyd, 1998; Zhang et al., 1998; Shimada et al., 2006). On geologic timescales, changes in oceanic exchange pathways, water properties and flux rates are critical parameters impacting the

\footnotetext{
* Corresponding author. Graduate School of Oceanography, University of Rhode Island, 215 South Ferry Road, Narragansett, Rhode Island 02882, USA.

E-mail address: oregan@gso.uri.edu (M. O’Regan).
}

evolution of ice in the Arctic Ocean, and as in other ocean basins require marine sediment records to decipher their history.

Information derived from marine sediments can also improve understanding of terrestrial ice-sheet dynamics (i.e. Knies et al., 2001; Spielhagen et al., 2004). These insights are critical as detailed reconstructions of pan-Arctic ice-sheets do not extend beyond the last two glacial cycles (Svendsen et al., 2004). The lack of a longerterm perspective on regional climate dynamics is exasperated by the comparatively short ice core records recovered from the Greenland ice-sheet, which do not extend beyond the last interglacial period (MIS 5) (North Greenland Ice Core Project members, 2004). In light of this, information obtained from marine sediments is a perquisite for furthering understanding of the Plio-Pleistocene evolution of the region.

Although a significant number of cores from the Arctic Ocean exist, the restricted length (generally $<10 \mathrm{~m}$ ) and difficulties in establishing chronologies due to the paucity of biostratigraphic markers and a complex downhole paleomagnetic signal (i.e. Backman et al., 2004) have largely prevented a well constrained chronology for sediments older than MIS 6/7. It was only through multi-national deep-sea 
drilling expeditions, such as the Ocean Drilling Program's (ODP) Leg 151 to the Yermak Plateau (Myhre et al., 1995), and IODP Leg 302 (Arctic Coring Expedition; ACEX) to the Lomonosov Ridge (Fig. 1) (Backman et al., 2006), that the required material to investigate environmental changes on longer timescales were recovered.

In this respect, the 197-m Neogene/Quaternary sequence recovered during ACEX provides an unprecedented view into paleoenvironmental changes that occurred in the central Arctic Ocean from the late early Miocene (Burdigalian) until the present (Moran et al., 2006; Backman et al., 2008). While the abundance of siliceous and organicwalled microfossils in pre-Neogene ACEX sediments allowed for a detailed Paleogene stratigraphy (Backman et al., 2008), Neogene/ Quaternary sediments are largely devoid of biogenic material that would otherwise be capable of providing isotopic and biostratigraphic constraints on sedimentation rates (Backman et al., 2008). However, the few biostratigraphic datums available, coupled with a robust estimate of average sedimentation rates derived from beryllium (Be) isotopes (Frank et al., 2008) have provided a framework for the Neogene/Quaternary chronostratigraphy (Backman et al., 2008) (Fig. 2a). This paper reviews the current status of the PlioPleistocene stratigraphy of the ACEX record, highlighting potential methods that can improve its resolution, and discuss, within the uncertainty of the current age model, the timing of important depositional changes during the Pleistocene.

\section{Methods}

This manuscript utilizes data from ACEX as well as two additional cores collected from the circumpolar regions of the Lomonosov Ridge; PS-2185-6 and 96/12-1PC (Fig. 1). The XRF core-scanning measurements of the ACEX cores were obtained directly at the split core surface of the archive half for the upper $20 \mathrm{~m}$ of the composite section using the XRF core scanner I at the University of Bremen (Röhl and Abrams, 2000), which is an updated version of the CORTEX scanner (Richter et al., 2006). The XRF scanner measurements were carried out with a $\operatorname{KEVEX}^{\odot}$ X-ray tube, a Mo detector, a generator setting of $20 \mathrm{kV}$ and a sampling time of $30 \mathrm{~s}$ to obtain the element intensities from $\mathrm{K}$ through to $\mathrm{Sr}$. The dimensions of the irradiated sediment surface was $1 \mathrm{~cm}$ x $1 \mathrm{~cm}$. To avoid contamination, the core surface was covered with a $100 \mu \mathrm{m}$-thin Polypropylene foil.

Coarse fraction contents of PS-2185-6 were acquired from the PANGAEA database (www.pangaea.de/PangaVista) (Spielhagen, 2005), while Jakobsson et al. (2001) previously published methods and results from grain size analyses on 96/12-1PC. Methods for quantifying the IRD components in the ACEX record are presented by St. John (2008). Seawater derived neodymium isotopes for both ACEX and PS-2185-6 were measured at the mass spectrometry facility of IFM-GEOMAR, Kiel, Germany, using the same methods as outlined in Haley et al. (2008a). Methods for acquiring the bulk density and $\mathrm{Arm} / k$ data presented in Fig. 4 were described by O’Regan et al. (2008a).

\section{Background}

\subsection{Core recovery}

ACEX targeted four sites on the Lomonosov Ridge, positioned along a $\sim 15 \mathrm{~km}$ segment of seismic line AWI-91090 (Fütterer, 1992; Jokat et al., 1992). Material recovered from three sites (M0002, M0003 and M0004) was used to generate a single composite depth scale. Overlapping recovery, sufficient to generate an accurate composite depth scale, was limited to the upper 20-25 mbsf, and was primarily recovered from two holes (M0003A, M0004C). The resulting uncertainties in the shallow part of the composite depth

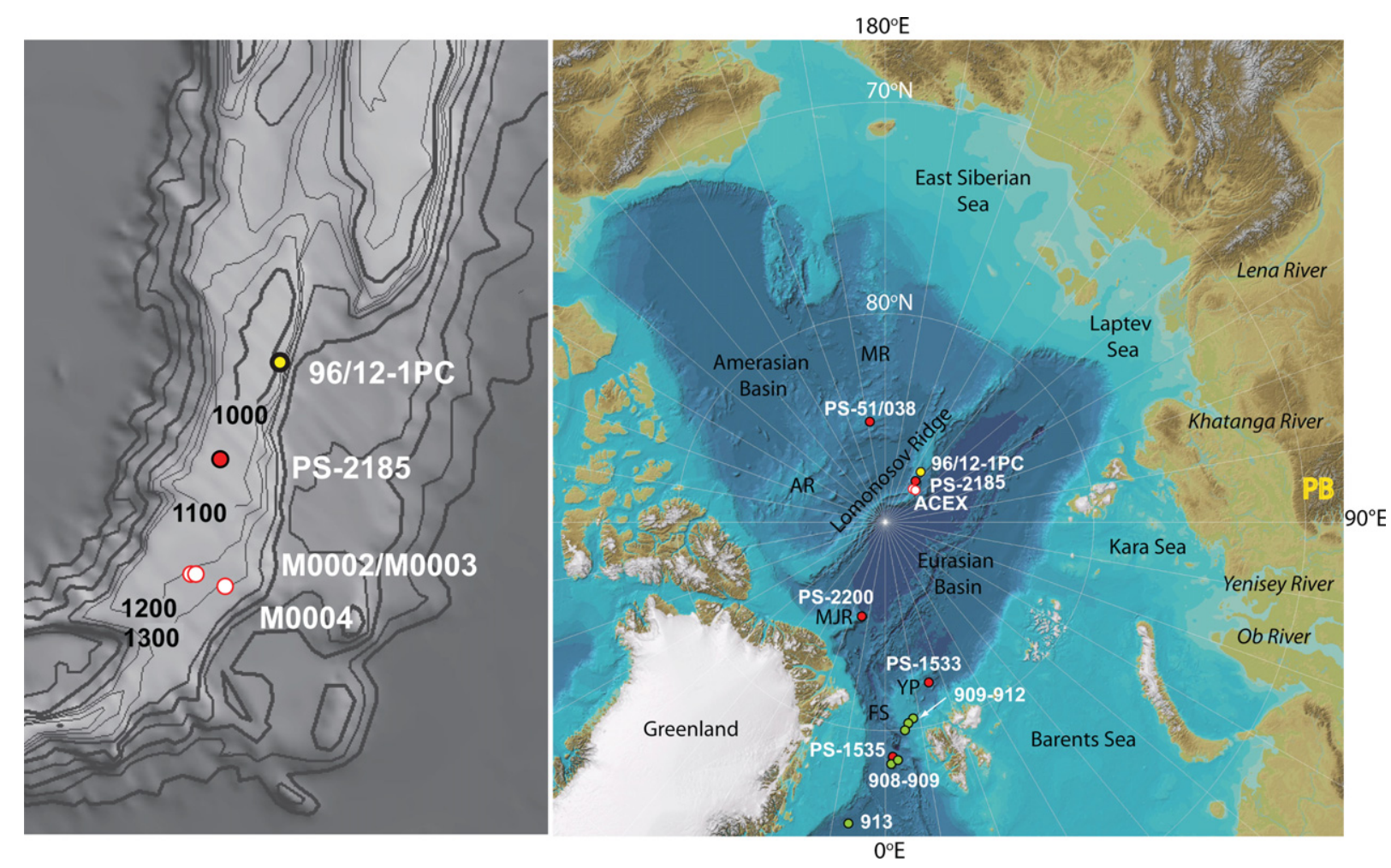

Fig. 1. A. Bathymetric map of the Arctic Ocean (Jakobsson et al., 2008). Download available from http://www.ngdc.noaa.gov/mgg/bathymetry/arctic/downloads.html. Locations and names of cores are shown for ACEX (white), 96/12-1PC (yellow), stratigraphically aligned cores from Spielhagen et al. (2004) (red) and sites from ODP Leg 151 (green). AR: Alpha Ridge, FS: Fram Strait, MJR: Morris Jessup Rise, MR: Mendeleev Ridge, YP: Yermak Plateau. Location of the Putorana flood basalts indicated by PB. B. Inset displaying a detail of the bathymetry of the LR in the vicinity of the ACEX sites, and the locations of stratigraphically aligned cores from O'Regan et al. (2008a). 

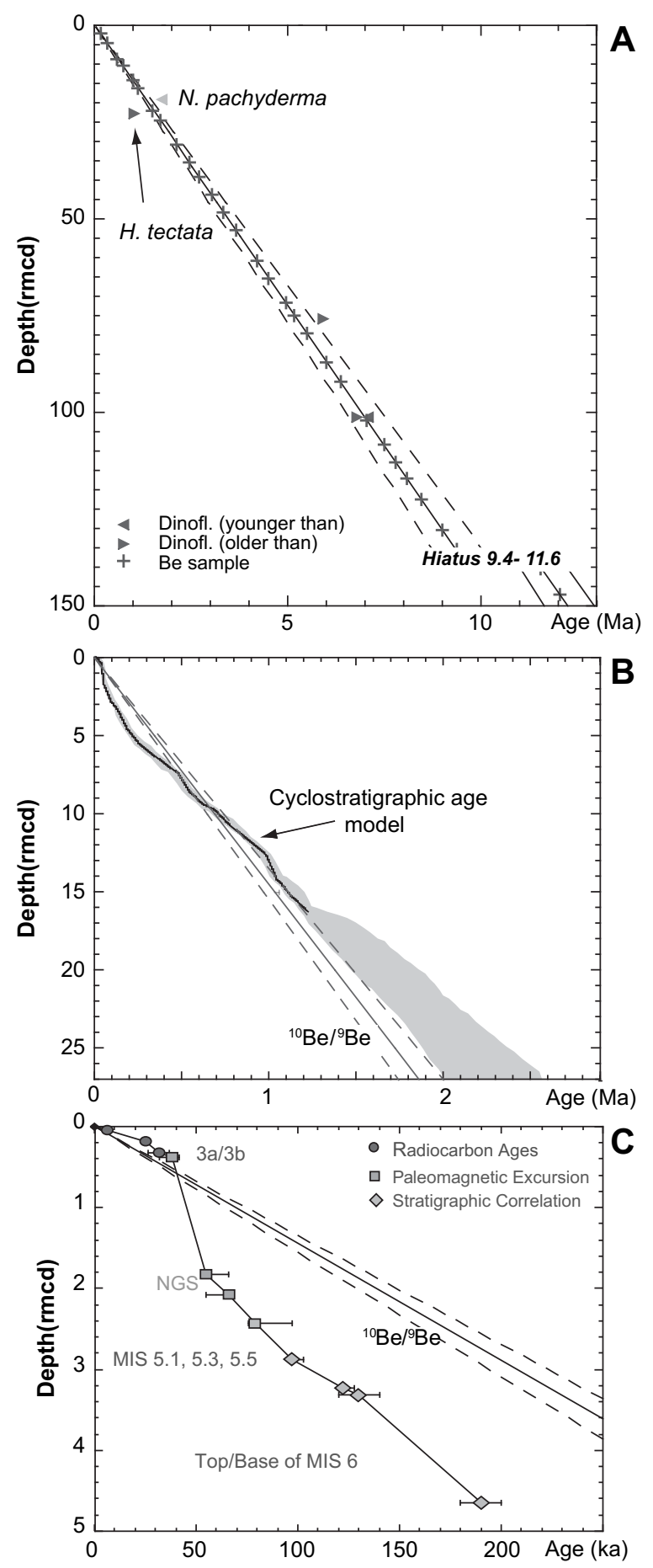

Fig. 2. A. The current age model for the upper $150 \mathrm{~m}$ of the ACEX composite record (Backman et al., 2008) B. Inset showing age markers for the last $200 \mathrm{kyr}$ (O'Regan et al. 2008a) compared with the ${ }^{10} \mathrm{Be} /{ }^{9} \mathrm{Be}$ estimate (Frank et al., 2008) used to define Neogene/Quaternary sedimentation rates $\mathrm{C}$. Comparison of the cyclostratigraphic age model presented by O'Regan et al. (2008b) and the ${ }^{10} \mathrm{Be} /{ }^{9} \mathrm{Be}$ estimate. Beyond $1.2 \mathrm{Ma}$ no definitive cyclostratigraphic age model exists, with the gray shading showing the divergence of the two published options (O'Regan et al., 2008b).

scale ( $<20$ mbsf) (Backman et al., 2006) were subsequently reduced by extending the stratigraphic correlation to two proximal cores (PS2185-6 and 96/12-1PC) (Fig. 1), of shorter length but deposited at lower sedimentation rates (O'Regan et al., 2008a). The revised composite depth scale (rmcd) (O'Regan et al., 2008b) is the one adopted in this manuscript.
Deeper than 27 rmcd, cores recovered from M0002A make up the remaining Neogene/Quaternary portion of the ACEX record, with approximately $75 \%$ recovery, but only $63 \%$ when intervals of core disturbance are removed (O'Regan et al., 2008b; Table 24 in Backman et al., 2006). Core disturbance was most pronounced between 26 and $80 \mathrm{rmcd}$, where only $47 \%$ of the recovered material was undisturbed. This is an important consideration when attempting to accurately define a Plio-Pleistocene chronology, as this interval extends from 1.8 to $5.5 \mathrm{Ma}$, when the age model presented by Backman et al. (2008) is applied.

\subsection{Biostratigraphic control}

The lack of preserved microfossils, capable of providing both isotopic and biostratigraphic constraints on the chronology of recovered sediments, remains a challenging aspect for deriving agecalibrated records from the Arctic Ocean (Backman et al., 2004). However, it is important to note that this disparity is not uniform with respect to time or recognized throughout all of the Arctic Ocean. For example, on the Lomonosov Ridge, calcareous nannofossils, and planktic/benthic foraminifera are present in varying quantities, especially within interglacial and interstadial deposits from the last $200 \mathrm{ka}$ (Jakobsson et al., 2001; Backman et al., 2004; Spielhagen et al., 2004). While in other locations including the Morris Jessup Rise (Spielhagen et al., 2004), Mendeleev Ridge (Polyak et al., 2004) and the Yermak Plateau (Knies and Gania., 2008), more continuous occurrences provide valuable biostratigraphic control points and permit the development of continuous $\delta^{18} \mathrm{O}$ and $\delta^{13} \mathrm{C}$ profiles to aid in paleoenvironmental and stratigraphic interpretations.

In the ACEX sedimentary sequence the intermittent occurrences of organic-walled dinoflagellate cysts and one planktic foraminiferal species ( $N$. pachyderma sinistral) have so far provided seven age-control points for the last $14 \mathrm{Ma}$ (Backman et al., 2008), two of which occur in the Pleistocene (Fig. 2a). The first is an isolated occurrence of $N$. pachyderma sinistral, observed at $19.33 \mathrm{rmcd}$, in a core that is stratigraphically constrained by overlapping recovery in multiple holes (O'Regan et al., 2008b). With a calibrated first occurrence (FO) in the Norwegian Greenland Sea (Spiegler, 1996) this datum constrains the age of the upper 19 rmcd of the ACEX record to less than $1.8 \mathrm{Ma}$. While a systematic study of foraminifera in the upper 18 rmcd was published by Cronin et al. (2008), the analysis of core material included M0004C-5X, M0004C-6X and M0004A-1H, $2 \mathrm{H}$ and $3 \mathrm{H}$, thus covering the upper $27 \mathrm{rmcd}$.

The second Pleistocene marker is a dinocyst $H$. tectata (22.69 rmcd) observed in a core with less certain stratigraphic alignment (M0004C-5X). The last occurrence (LO) of H. tectata is near the base of the Jaramillo (1.1 Ma). However, this marker is not a true LO, as no other dinoflagellate cysts were observed in the samples analyzed above, and as such, it can only tell us that sediments below 22.69 rmcd are older than $1.1 \mathrm{Ma}$ (Backman et al., 2008). The current inventory of Pliocene and Miocene dinocyst markers are limited and primarily based on core catcher samples; a more detailed recognition and calibration of events is expected to provide a framework for improving the existing chronology (Matthiessen et al., 2009).

\subsection{Stratigraphic correlation and cyclostratigraphy}

The regional stratigraphic correlation presented by O'Regan et al. (2008a, 2008b) improved not only the inter-site/hole alignment of the ACEX material, but allowed detailed age-control points developed on PS-2185-6 by Spielhagen et al. (2004) and 96/12-1PC by Jakobsson et al. $(2000,2001,2003)$ to be mapped onto the ACEX record, thereby constraining the chronology for the last two glacial cycles. The age models for these two neighboring cores, and 
particularly the identification of MIS 5 through 6/7 are constrained by multiple lines of evidence that include calcareous nannofossil occurrences and abundances (Jakobsson et al., 2000, 2001; Spielhagen et al., 2004), optically stimulated luminescence dating (Jakobsson et al., 2003), a regional stratigraphic correlation utilizing paleomagnetic, sedimentological and isotopic $\left(\delta^{18} \mathrm{O}\right.$ and $\left.{ }^{10} \mathrm{Be}\right)$ data (Spielhagen et al., 2004) and most recently through amino acid racemization (Kaufman et al., 2008).

When the more constrained chronology for the last $200 \mathrm{ka}$ is compared to the ${ }^{10} \mathrm{Be} /{ }^{9} \mathrm{Be}$ chronology (Fig. 2b,c) it becomes clear that the average sedimentation rate adopted for the Neogene/ Quaternary material at ACEX does not account for the short-term variations in sedimentation rate required to resolve glacial/interglacial variability at predicted Milankovitch frequencies. There are a number of competing reasons for this observation. The most obvious is that the age model derived from beryllium decay rates adopts a best-fit line, which, by definition, removes short-term deviations. This is an important consideration as the linear sedimentation rate for the last $200 \mathrm{ka}(24.5 \mathrm{~m} / \mathrm{Myr})$ is substantially higher than the cyclostratigraphic derived estimates for the interval between 0.19 and $1.2 \mathrm{Ma}(11.3 \mathrm{~m} / \mathrm{Myr}$ ) (O'Regan et al., 2008a). When compared to the ${ }^{10} \mathrm{Be} /{ }^{9} \mathrm{Be}$ chronology, these short-term variations balance out, and by $0.8 \mathrm{Ma}$, the cyclostratigraphic and beryllium age models converge (Fig. 2c).

However, equally important considerations regarding the interpretation of the ${ }^{10} \mathrm{Be} /{ }^{9} \mathrm{Be}$ data are highlighted by recent results from a high-resolution study on two cores from the Alpha and Mendeleev Ridges. In this study, a ${ }^{10} \mathrm{Be} /{ }^{9} \mathrm{Be}$ derived chronology, acquired at a higher sampling resolution than the ACEX cores, provides an order of magnitude slower sedimentation rate when compared to constraints from biostratigraphic, cyclostratigraphic and amino acid racemization analyses (Sellén et al., 2009). This discrepancy is attributed to a lower ${ }^{10} \mathrm{Be} /{ }^{9} \mathrm{Be}$ ratio of seawater in Amerasian Basin cores during the later part of the Pleistocene. It likely represents a regional effect arising from a less pronounced influence exerted by Atlantic intermediate waters in the Amerasian Basin, or by more persistent sea ice cover when compared to the Eurasian Basin and the location of the ACEX drill sites. Further understanding of the temporal and spatial variability in the ${ }^{10} \mathrm{Be} /{ }^{9} \mathrm{Be}$ of seawater in the Arctic Ocean, and how this relates to environmental changes, requires a comparison between ${ }^{10} \mathrm{Be} /{ }^{9} \mathrm{Be}$ chronologies acquired at comparable resolutions from the Amerasian and Eurasian basins.

While multiple indicators between MIS 7 and the present constrain the ages of sediments from ACEX and other stratigraphically aligned cores from the central Arctic Ocean (Fig. 1), prior to ACEX only a single age model was suggested for sediments older than the MIS 6/7 boundary. This age model was based on a visual correlation between bioturbated Mn enriched intervals in 96/12-1PC (Jakobsson et al., 2000) and a low latitude record of $\delta^{18} \mathrm{O}$ (Bassinot et al., 1994). A comparison of multiple sedimentological measurements including color data, XRF core scanning Mn data, high-resolution bulk density, compressional wave velocity, magnetic grain size proxies and abundances of benthic agglutinated foraminifera, illustrated that all these parameters co-vary within sediments older than MIS 6/7 (O'Regan et al., 2008a). These variables also display pronounced cyclicity despite a dramatic reduction in the variability of the coarse fraction content between glacial and interglacial stages below the MIS 6/7 boundary (Fig. 3). This reduction in coarse fraction material $(>63 \mu \mathrm{m})$ is exemplified by comparing the abundance during MIS 4 and 6 in PS-2185-6, which is 27 and $24 \%$ wt. respectively (Spielhagen et al., 2004), to the overall variability seen in sediments older than MIS 6, which is generally $<10 \%$ wt. during both glacial and interglacial periods in PS-2185-6, 96/12-1PC and the ACEX record (Fig. 3; Fig. 4a).
The interglacial/interstadial enrichment in Mn, a characteristic feature of the ACEX, PS-2185-6 and 96/2-1PC records, is attributed to either enhanced flux of Mn to the central Arctic during de-glacial or interglacial periods, or from sluggish intermediate and deep-water circulation during glacial times (Jakobsson et al., 2000). In the latter case, it is argued that stagnant bottom and intermediate waters lead to dysoxia, with Mn only precipitating into the sediments during ventilated interglacial/interstadial periods. A recent analysis of XRF core scanning data from 96/12-1PC has shown that the downhole Mn abundance is not strongly correlated with other redox sensitive elements, partially supporting the argument that it records a primary depositional signal (Löwemark et al., 2008), and is in keeping with the observation that it varies in phase with changes in bulk and mineral grain size proxies, the occurrence of bioturbation, and the abundance of benthic agglutinated foraminifera (O'Regan et al., 2008a). The neodymium isotopic composition of sediments from PS-2185-6 and ACEX show similarly paced variations, with less radiogenic values reflecting a larger influence from Atlantic intermediate waters during interglacials, and a shift towards more radiogenic values representing a larger influence exerted by brine rejection during glacials (Haley et al., 2008a) (Fig. 3).

An interesting observation is that dysoxia of intermediate and deep waters during glacial intervals is an unlikely mechanism for the origin of Mn cycles if the Lomonosov Ridge is bathed in waters supersaturated in oxygen derived from brine rejection. This certainly lends support to the interpretation that Mn enrichment in interglacials originated from an enhanced flux of Mn from circumArctic rivers, or from flooding of the submerged shelves. While the exact mechanisms remain unresolved, Mn enrichment in central Arctic sediments during interglacials and interstadials remains an important and pervasive feature of Pleistocene sediments.

As the discussion on the Mn enrichment highlights, some uncertainty remains on the mechanisms driving past lithologic variations recorded in cores from the central Arctic, nonetheless, recognized variability in multiple sedimentological, geochemical and micropaleontological variables provides a means for investigating cyclostratigraphic patterns in the deposition of the sediments. Using these parameters and the additional biostratigraphic constraints from the ACEX record, a preliminary cyclostratigraphy was derived that extends back to 1.2 Ma (O'Regan et al., 2008a) (Fig. 2c). The published cyclostratigraphic age model is presented with large error bars that account for uncertainty in the forcing mechanism/tuning target, and for different but equally acceptable interpretations (O'Regan et al., 2008a). Increased resolution of the age model requires additional constraints to identify terminations of glacial stages, which in the absence of isotopic data, could be achieved by an improved understanding of the long duration of the geomagnetic excursions found throughout central Arctic sediments, the possible development and inclusion of relative paleointensity data, or the identification of a unique sedimentological signature that can be tied to ice-sheet collapse on the surrounding margins (Vogt and Knies, 2008).

Beyond $1.2 \mathrm{Ma}$, lithologic variability in the ACEX record continues, but depending on whether it is primarily attributed to precessional or obliquity paced forcing, leads to two differing interpretations with age errors that exceed the duration of glacial cycles recorded in the Matuyama (O'Regan et al., 2008a) (Fig. 2c). The end of a complete composite section at $27 \mathrm{rmcd}$, and the dramatic reduction in core quality between 26 and $80 \mathrm{rmcd}$ (Fig. 4d), were primary factors preventing better resolution of the cyclostratigraphy. Therefore, while both options for sedimentation rates in the Matuyama remain possibilities, it is the age model with strong precessional control that best fits with the average Neogene/ Quaternary sedimentation rate. Alternatively, the slower age model ultimately requires a large sediment flux in the Pliocene for it to be 

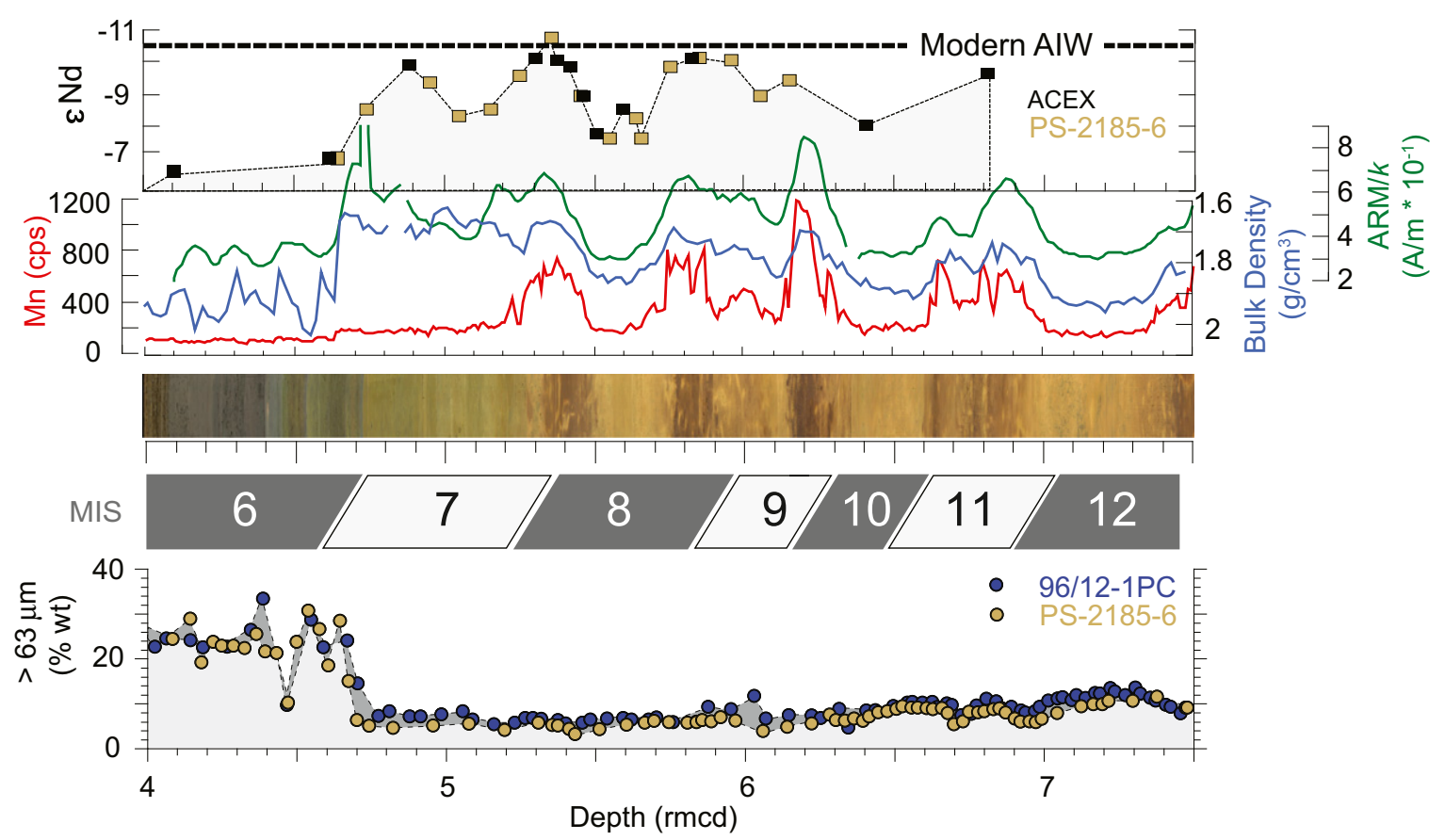

Fig. 3. Stratigraphically aligned physical, magnetic, sedimentological and isotopic data from ACEX, PS-2185-6 and 96/12-1PC. Lows in bulk density (a proxy for grain size) correlate to peaks in Mn abundance and 'finer' magnetic grain sizes (ARM/k) that all occur during the dark brown bioturbated intervals that characterize interglacial/interstadial deposits. Lithologic changes are shown to coincide with \&Nd isotopic variations. Bottom panel shows the stratigraphically aligned coarse fraction contents from PS-2185-6 and 96/12-1PC. Proposed ages from the cyclostratigraphic ACEX age model are shown with sub-vertical lines used to illustrate uncertainty of stage boundaries (O'Regan et al., 2008a).

reconciled to the long-term ${ }^{10} \mathrm{Be} /{ }^{9} \mathrm{Be}$ age model, biostratigraphic control points in the late Miocene and paleomagnetic interpretations of the early and middle Pliocene (Backman et al., 2006; 2008; O'Regan et al., 2008a).

\section{Plio-Pleistocene IRD records}

Within the established framework it is possible to investigate prominent depositional changes, as long as the required level of prudence is taken when defining exact ages for events. One clear example is through better defining trends in the ice rafted debris (IRD) content of the ACEX record.

A detailed study of the terrigenous components of the coarse fraction material from the ACEX cores, namely the 150-250 and $>250 \mu \mathrm{m}$ size fractions, was presented by St. John (2008). These results indicate that ice was present in the Arctic since the midEocene, and at the resolution attained in her study ( $\sim 58 \mathrm{kyr}$ for the Plio-Pleistocene, and up to $100 \mathrm{kyr}$ for the middle Miocene), was present throughout the Neogene/Quaternary. Taking a more detailed look at the IRD records in the Plio-Pleistocene reveals interesting trends. First is the high flux rates that dominate the preserved material from the last two glacial cycles (Fig. 4), when reconstructions indicate that marine based ice-sheets were present on the Barents-Kara shelf (Svendsen et al., 2004), and glacial erosion is mapped to a water depth of approximately $>1000 \mathrm{~m}$ below present sea-level and dated to MIS 6 within $200 \mathrm{~km}$ of the ACEX sites (Jakobsson et al., 2008). These trends suggest an environment where debris-laden masses of ice, sourced from marine based ice-sheets, extended into the central Arctic Ocean.

Below 4.65 rmcd (equivalent to the base of MIS 6) the recurrent coarse-grained lithofacies of the last two glacial cycles is no longer seen. Instead there is a comparatively low and stable concentration of terrigenous IRD and coarse fraction content that exists between 4.65 and $\sim 19 \mathrm{rmcd}$. At $19 \mathrm{rmcd}$ there is a notable upcore reduction in the abundance of the $150-250 \mu \mathrm{m}$ component (Fig. 4). The presence of $N$. pachyderma sin. at 19.33 rmcd (Figs. 2a and 4) indicates that the reduction in IRD has a maximum age of $1.8 \mathrm{Ma}$, while the ${ }^{10} \mathrm{Be} /{ }^{9} \mathrm{Be}$ age model indicates a younger age of $1.3 \mathrm{Ma}$ (Fig. 2a).

The observed decrease in IRD is not an artifact of splicing material from different sites, as the data in the upper $19 \mathrm{rmcd}$ are compiled from cores in M0004C and M0003A (located $\sim 15 \mathrm{~km}$ apart) and the material below $19 \mathrm{rmcd}$ form cores in M0004C and M0002A (located $3 \mathrm{~km}$ apart). Similarly, converting these depth trends into flux rates better defines the low between 4.65 rmcd and 19 rmcd as the cyclostratigraphic age model shows lower than average sedimentation rates between the base of MIS 6 (4.65 rmcd) and at least $16.23 \mathrm{rmcd}$ (Fig. 2c) (O'Regan et al., 2008a).

An alluring interpretation for the reduction in IRD at $\sim 19$ rmcd would be the transition from 'seasonal' to multi-year (i.e., 'perennial') sea ice conditions. However, this does not fit with other data from ACEX. For example, reconstructions of ice-drift paths and provenance indicate that a perennial ice-cover was first established in the Arctic Ocean before $12 \mathrm{Ma}$ (Krylov et al., 2008; Darby, 2008; Haley et al., 2008a, 2008b). While some of this evidence is based upon assumptions of ice-drift speeds that may not be correct, it should also be noted that a perennial ice coverage is also inferred from the generally smooth but coarse resolution exponential decrease of ${ }^{10} \mathrm{Be} /{ }^{9} \mathrm{Be}$ with depth in the Neogene/Quaternary ACEX sediments (Frank et al., 2008). Existing evidence also suggests that the long-term presence of multi-year ice was accompanied by the growth of Eurasian ice sheets, inferred by the invariable Eurasian source for the detrital material of the sediments on the Lomonosov Ridge over the past $15 \mathrm{Myr}$ (Haley et al., 2008b) and the existence of glacially eroded material in sediments from the Fram Strait (ODP site 909) during the so-called Middle Miocene Climate Transition 15-14 million years ago (Knies and Gaina, 2008).

Accepting that multi-year ice was present in the central Arctic since the Miocene, the low and uniform abundance of IRD that characterizes the bulk of the Pleistocene may signify the 
A

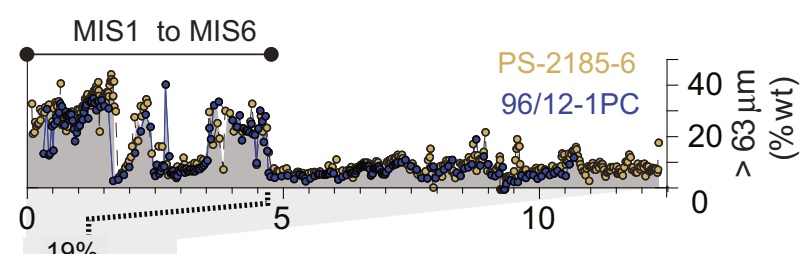

B
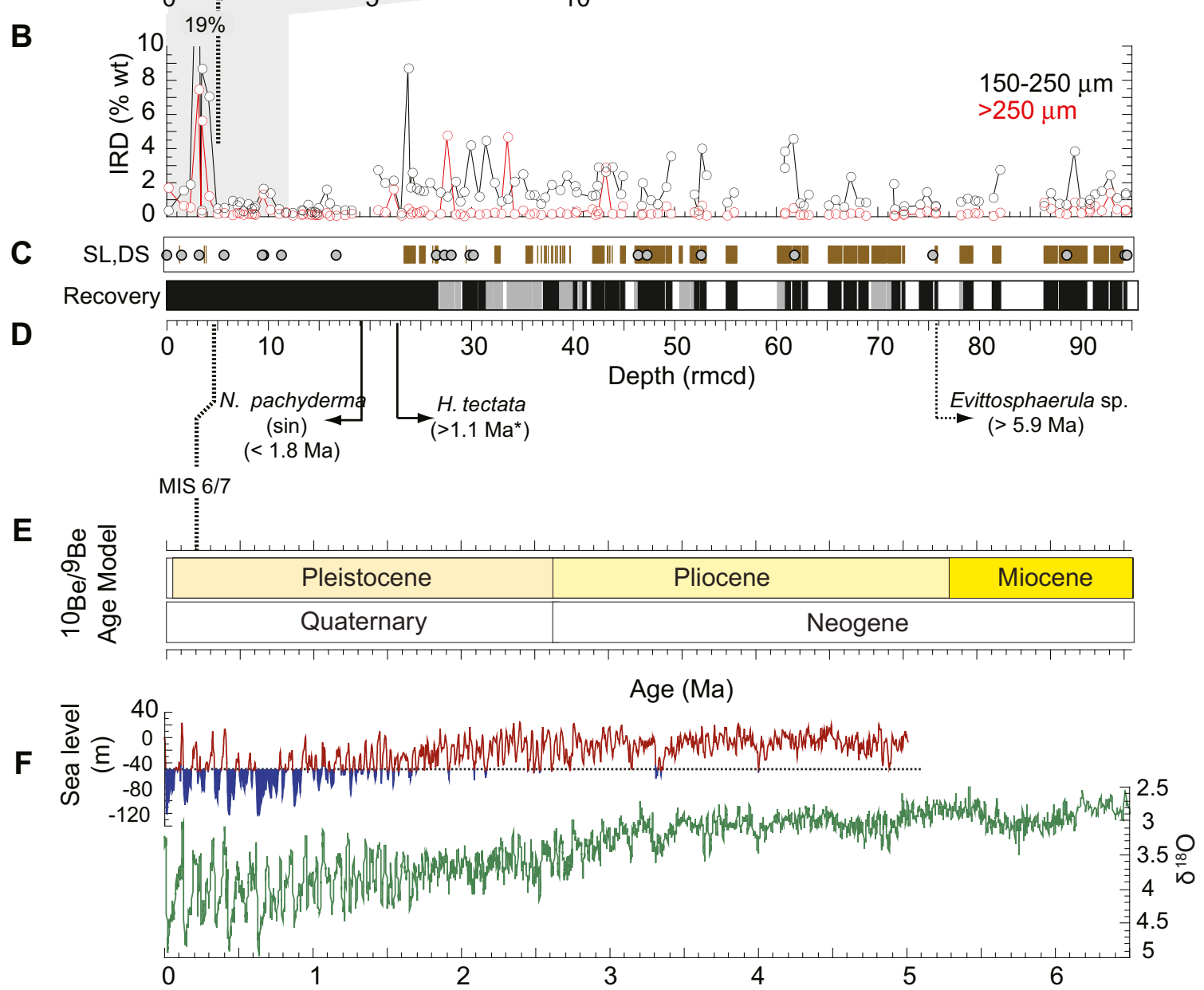

Fig. 4. Summary figure showing A Stratigraphically aligned coarse fraction contents from PS-2185-6 and 96/12-1PC shown on the ACEX revised composite depth scale. B. Terrigenous IRD abundance from ACEX (St. John, 2008), C. Occurrence of drop stones (> $5 \mathrm{~mm}$ diameter) and sand lenses from visual core descriptions (Backman et al., 2006), D. Core recovery (black = total recovery; grey= disturbed). E. ${ }^{10} \mathrm{Be} /{ }^{9} \mathrm{Be}$ derived age model for the last 6.5 Myr. Also shown are existing biostratigraphic constraints. Dashed lines highlight existing discrepancies between age models/markers. F. Global sea-level (Miller et al., 2007) and global benthic $\delta^{18} \mathrm{O}$ compilation (Zachos et al., 2001; Lisiecki and Raymo, 2005). Blue shading of the sea-level curve indicates times when global sea-level dropped below $-50 \mathrm{~m}$ and the Bering Strait was likely exposed.

development of a more stable ice-pack, with decreased rates of seasonal melting. This interpretation is consistent with the comparatively low sedimentation rates during this time, which rule out the possibility that a uniform IRD supply is being diluted by surface/intermediate current controlled deposition of terrigenous fines. An important alternative to a change in the sea ice regime is that the more variable IRD abundance beneath $19 \mathrm{rmcd}$, which also corresponds to an apparent increase in the frequency of sand lenses in the recovered cores (taken from visual core descriptions; Backman et al., 2006) (Fig. 4c), may indicate stronger paleocurrent speeds at the intermediate depths $(1200 \mathrm{mbsl})$ of the drill sites.

A link between circulation changes and the reduction in IRD abundance in the early part of the Pleistocene is strengthened by a near synchronous shift in the variability of Nd isotopes. Haley et al. (2008a) report that a break from a long-term stable and positive $\varepsilon N d$ signature related to brine rejection occurs at $\sim 2 \mathrm{Ma}$ (in samples from between 21-24 rmcd). The initial shift is towards more positive (radiogenic) $\varepsilon N d$ values that they associate with the growth of large ice sheets on the Arctic shelves, principally the Kara shelf where the Putorana flood basalts (part of the Siberian Trap system) are a major source for highly radiogenic Nd (Fig. 1). This depth marks the start of large-scale $( \pm 4 \varepsilon N d)$ variations that reflect the millennial scale interplay between brine rejection and North Atlantic (NA) inflow as sources Arctic Intermediate Water, a water mass that is found today between 200 and 1500 mbsl and bathes the Lomonosov Ridge (Haley et al., 2008a).

At first glance it seems difficult to reconcile a shift towards more intense millennial scale variations in the inflow of Atlantic water with either less intense intermediate water circulation (if the abundance of sand lenses reflects current winnowing), or a more stable sea ice cover (if the low IRD abundance recorded for the bulk of the Pleistocene reflects reduced melting/transport of ice across the drill sites). Speculations on how these processes may be linked are derived from modern patterns of circulation and sea ice stability, and how circulation patterns would be predicted to change through the Plio-Pleistocene. 


\section{Gateway evolution, circulation and ice-cover}

With the growing availability and analysis of instrumental records, the influence of changing circulation patterns on the stability of the Arctic's ice pack is increasingly being recognized. In modern times, exchanges with both the Pacific and Atlantic Oceans have a profound impact on the vertical structure and surface heat flux of the Arctic, with the cold halocline layer insulating sea ice from warm saline Atlantic waters that enter through the Fram Strait and across the Barents Shelf (Rudels et al., in press; Steele and Boyd, 1998). Sea ice is produced from the low salinity surface waters formed from both river input and the relatively fresh Pacific water that enters through the Bering Strait (Aagaard et al., 1981). Assuming that gateway exchanges played a similarly important role in the past, it is helpful to look at what is known about their geologic evolution and how this may be linked to observed patterns of IRD in the central Arctic Ocean.

\subsection{Pacific inflow}

As much as a third of the total 'freshwater' influx to the Arctic Ocean enters through the Bering Strait and is considered a primary mechanism for the occurrence and maintenance of the modern perennial sea ice cover (Woodgate and Aagaard, 2005). However, in the summer, Pacific water inflow also provides the largest heat source for basal melting of sea ice in the Beaufort Gyre (Shimanda et al., 2001). The sensitivity of the Arctic ice pack to variations in Pacific water inflow was recently illustrated by a spatial link between regions of accelerated sea ice reduction (Serreze et al., 2003) and an increase in the amount of warm Pacific Summer Water that entered the upper halocline of the Canadian Basin during the 1990s (Shimada et al., 2006).

Considering that the average sill depth across the Bering Strait is only $50 \mathrm{mbsl}$ and ignoring isostatic influences, global sea-level reconstructions indicate that it was in the early part of the Pleistocene when a land bridge would first develop during glacial periods (Fig. 4f). The overall reduction in IRD abundance in the ACEX record (with a youngest date of $1.3 \mathrm{Ma}$ ) closely coincides with the timing of glacial closures of the Bering Strait. It's periodic closure may have allowed a more stable (thicker) sea ice cover to develop by either lowering the heat flux into the halocline, or modifying wind-driven circulation patterns and increasing the residence time of surface waters (De Boer and Nof, 2004; Hu et al.,
2007). This reorganization would imply a change in the position/ strength of the transpolar drift and ultimately ice-export through the Fram Strait (Bischof and Darby, 1997). However, it remains difficult to evaluate how these potential positive impacts on sea ice stability balance the negative impacts associated with the loss of the less saline Pacific waters in the upper surface layer of the Arctic.

Furthermore, the 50-m isobath required to cut-off exchange with the Pacific also exceeds the mean depth of the Laptev Sea $(48 \mathrm{~m})$ and exposes significant portions of the East Siberian Sea (58 m), Chukchi Sea (80 m) and the Beaufort Sea (124 m) (Fig. 5b) (Jakobsson, 2002). These are regions where the majority of sea ice is formed today. The location and vigor of sea ice production, and the dominant sediment entrainment processes when these shallow shelves were largely exposed, remains unknown.

\subsection{North Atlantic inflow}

Northward flowing Atlantic waters carry significant amounts of heat into the Arctic Ocean, with the estimated heat transport in the West Spitsbergen current alone being comparable to the atmospheric heat transport across $80 \mathrm{oN}$ (Rudels et al., in press). Modern observations and modeling have also shown that a reduction in sea ice cover within the Eurasian Basin occurs with increased flux of warm NA waters (Steele and Boyd, 1998; Zhang et al., 1998).

There are two paths through which NA water enters the Arctic Ocean. After entering the Norwegian Greenland Seas across the eastern Greenland-Scotland Ridge, NA water diverges, with a portion entering the Barents Sea, while the remainder travels north through the Fram Strait via the West Spitsbergen current. NA waters entering through the Fram strait are generally subducted to intermediate water depths where they form a relatively warm high salinity water mass that flows as an eastern boundary current along the Eurasian margin. This water mass continues to circulate throughout the Arctic Ocean before exiting the Fram Strait. Conversely, the NA waters that cross the Barents and Kara seas are subject to strong mixing processes and wintertime heat loss (Rudels et al., 1999).

In modeling experiments, an exposed Barents Shelf re-directs NA water entirely through the Fram Strait, warming intermediate waters and reducing the thickness of the ice pack in the central Arctic (Butt et al., 2002). While it is generally accepted that the Barents Sea was exposed in the Pliocene and early Pleistocene (Torsvik et al., 2002), the exact timing of its erosion/submergence
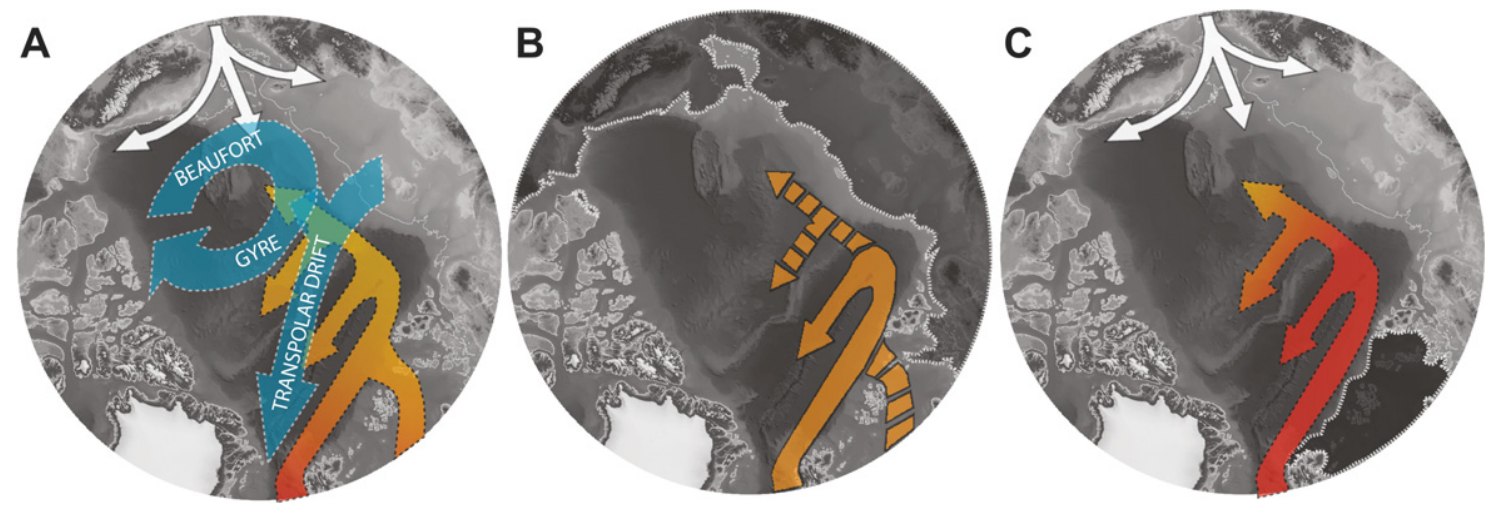

Fig. 5. Gateway evolution and circulation patterns. A. Generalized surface (blue) circulation of the Arctic Ocean. Red/Orange arrows conceptually represent heat loss as surface waters from the North Atlantic enter the Arctic and become subducted and intermixed. B. For much of the last 1-1.5 Ma global sea-level was more than $50 \mathrm{~m}$ below the present day level. Ignoring isostatic effects, this implies that the Bering Strait would be closed and much of the surrounding shelves exposed. The Barents Sea branch, and overall penetration of Atlantic Waters into the Amerasian Basin are shown with dashed arrows indicating intermittent or uncertain extent during past glacial periods. Position of the Beaufort Gyre and Trans-Polar drift are not shown. C. Through the Pliocene and early Pleistocene the Barents Sea was exposed, and North Atlantic waters were channeled through the Fram Strait carrying more heat into the interior basin, while Pacific water entered via the Bering Strait. Position of the Beaufort Gyre and Trans-Polar drift are not shown. 
remains loosely constrained by seismic data collected on the western Svalbard - Barents Sea margin. These data indicate that prior to $2 \mathrm{Ma}$ it was exposed, and became a predominantly shelf sea by $1 \mathrm{Ma}$ (Butt et al., 2002). Prior to its submergence, an equal flux of Atlantic water into the NGS is predicted to result in more heat being channeled into the central Arctic, potentially increasing the amount of seasonal melting of the ice cap. The submergence of the Barents shelf certainly falls within the estimated range of dates for the reduction of IRD seen in the ACEX record, and provides a mechanism that can potentially explain the sudden change in either intermediate current strength and/or sea ice stability that persists across glacial and interglacial cycles for the bulk of the Pleistocene.

\subsection{Summary}

The glacial closure of the Bering Strait and the erosion/ submergence of the Barents Shelf are loosely constrained gateway events that, to a first order, do appear linked with the reduction in IRD abundance that occurs in Pleistocene sediments from ACEX. An open Bering Strait and channeled in-flow through the Fram Strait are the postulated gateway conditions during the Pliocene and early part of the Pleistocene. Both can account for enhanced icemelting (and therefore higher IRD abundances) by increasing the amount of heat available for basal melting of the established ice pack (Fig. 5). However, equally tenable are changes to the strength of intermediate water circulation induced by these different gateway conditions, potentially elevating the apparent IRD content of Pliocene sediments via winnowing. Differentiating the influence on grain size exerted by sea ice and current sorting remains a critical aspect required to unravel the mechanisms driving lithologic changes in Plio-Pleistocene sediments from the Lomonosov Ridge and other parts of the Arctic Ocean.

\section{Conclusions}

The outlined Plio-Pleistocene chronostratigraphic framework of the ACEX record is coupled with data-sets that describe changes in the intensity of ice-cover and/or paleocirculation patterns. Together these results indicate that while a perennial ice cover likely existed within the Arctic from at least the middle Miocene, there was a notable reduction in the amount of IRD delivered to the central Arctic in the early part of the Pleistocene. This condition persisted until the MIS 6/7 boundary. While existing evidence suggests that the recurrent coarse-grained lithofacies charactering the last two glacial cycles is likely related to the development of large marine based ice-sheets on the Barents and Kara shelves (Spielhagen et al., 2004), why this suddenly occurred at the MIS 6/7 boundary remains unresolved.

The reduction in IRD in the early part of the Pleistocene is interpreted as arising from either a shift towards a more stable ice pack, or a decrease in the strength of intermediate water circulation. Its occurrence is linked with changes to both the inflow of Pacific and Atlantic waters, which in modern times, are known to exert a strong influence on sea ice stability. Future studies that help resolve the timing for the submergence of the Barents Shelf and Bering Strait, the flux and properties of waters entering these gateways, and the resulting vertical structure of Arctic Ocean water masses are required to evaluate the importance of these exchanges in relation to sea ice stability across glacial and interglacial periods.

\section{Acknowledgements}

Financial support was provided by VR (JB and MJ), NSF (ODP) grant 0623220 (to KM and JK), and the Deutsche Forschungsgemeinschaft (to UR). This research was conducted with samples and data from the Integrated Ocean Drilling Program (IODP), an international marine research program dedicated to advancing scientific understanding of the Earth, the deep biosphere, climate change, and Earth processes by sampling and monitoring subseafloor environments.

\section{References}

Aagaard, K., Coachman, L.K., Carmack, E., 1981. On the halocline of the Arctic Ocean. Deep Sea Research, Part A 28, 529-545.

Aagaard, K., Carmack, E.C., 1994. The Arctic Ocean and climate: a perspective. Maurice Ewing Series. In: Johannessen, O.M., Muensch, R.D., Overland, J.E. (Eds.), The Polar Oceans and Their Role in Shaping the Global Environment, pp. 5-20. 85.

Backman, J., Jakobsson, M., Løvlie, R., Polyak, L., Febo, L.A., 2004. Is the central Arctic Ocean a sediment starved basin? Quaternary Science Reviews 23, 1435-1454.

Backman, J., Moran, K., McInroy, D.B., Mayer, L.A. (Eds), 2006. Proceedings IODP 302 , Edinburgh (Integrated Ocean Drilling Program Management International, Inc.). doi:10.2204/iodp.proc.302.2006.

Backman, J., Jakobsson, M., Frank, M., Sangiorgi, F., Brinkhuis, H., Stickley, C., O’Regan, M., Løvlie, R., Pälike, H., Spofforth, D., Gattacecca, J., Moran, K., King, J., Heil, C., 2008. Age model and core-seismic integration for the Cenozoic Arctic Coring Expedition sediments from the Lomonosov Ridge. Paleoceanography 23, PA1S03. doi:10.1029/2007PA001476.

Bassinot, F.C., Labeyrie, L.D., Vincent, E., Quidelleur, X., Shackleton, N.J., Lancelot, Y., 1994. The astronomical theory of climate and the age of the Brunhes-Matuyama magnetic reversal. Earth Planetary Science Letters 126, 91-108.

Bischof, J.E., Darby, D., 1997. Mid- to Late Pleistocene Ice Drift in the Western Arctic Ocean: evidence for a different circulation in the past. Science 277, 74-78. doi:10.1126/science.277.5322.74.

Butt, F.A., Drange, H., Elverhøi, A., Otterå, O.H., Solheim, A., 2002. Modelling Late Cenozoic isostatic elevation changes in the Barents Sea and their implications for oceanic and climatic regimes: preliminary results. Quaternary Science Reviews 21, 1643-1660.

Cronin, T., Smith, S.A., Eynaud, F., O'Regan, M., King, J., 2008. Quaternary paleoceanography of the central Arctic based on Integrated Ocean Drilling Program Arctic Coring Expedition 302 foraminiferal assemblages. Paleoceanography 23, PA1S18. doi:10.1029/2007PA001484.

Darby, D.A., 2008. Arctic perennial ice cover over the last 14 million years. Paleoceanography 23, PA1S07. doi:10.1029/2007PA001479.

De Boer, A.M., Nof, D., 2004. The exhaust valve of the North Atlantic. Journal of Climatology. 17, 417-422.

Frank, M., Backman, J., Jakobsson, M., Moran, K., O’Regan, M., King, J., Haley, B.A., Kubik, P.W., Garbe-Schönberg, D., 2008. Beryllium isotopes in central Arctic Ocean sediments over the past 12.3 million years: Stratigraphic and paleoclimatic implications. Paleoceanography 23, PA1S02. doi:10.1029/ 2007PA001478

Fütterer, D.K., 1992. Arctic '91: the expedition ARK VIII/3 of RV “Polarstern” in 1991. Berichte zur Polarforschung 107, 1-267.

Haley, A.B., Frank, M., Spielhagen, R.F., Eisenhauer, A., 2008a. Influence of brine formation on Arctic Ocean circulation over the past 15 million years. Nature Geoscience 1, 68-72.

Haley, B.A., Frank, M., Spielhagen, R.F., Fietzke, J., 2008b. Radiogenic isotope record of Arctic Ocean circulation and weathering inputs of the past 15 million years. Paleoceanography 23, PA1S13. doi:10.1029/2007PA001486.

Hu, A., Meehl, G.A., Han, W., 2007. Role of the Bering Strait in the thermohaline circulation and abrupt climate change. Geophysical Research Letters 34, L05704. doi:10.1029/2006GL028906.

Jakobsson, M., Løvlie, R., Al-Hanbali, H., Arnold, E., Backman, J., Mörth, M., 2000. Manganese and color cycles in Arctic Ocean sediments constrain Pleistocene chronology. Geology 28, 23-26.

Jakobsson, M., Løvlie, R., Arnold, E., Backman, J., Polyak, L., Knudsen, J., Musatov, E., 2001. Pleistocene stratigraphy and paleoenvironmental variation from Lomonosov Ridge sediments, central Arctic Ocean. Global and Planetary Change 31, $1-22$.

Jakobsson, M., 2002. Hypsometry and volume of the Arctic Ocean and its constituent seas. Geochemistry, Geophysics, Geosystems 3, 1-18.

Jakobsson, M., Backman, J., Murray, A., Løvlie, R., 2003. Optically stimulated luminescence dating supports central Arctic Ocean cm-scale sedimentation rates. Geochemistry, Geophysics, and Geosystems 4 (2). doi:10.1029/ 2002GC000423.

Jakobsson, M., Macnab, R., Mayer, M., Anderson, R., Edwards, M., Hatzky, J., Schenke, H.-W., Johnson, P., 2008. An improved bathymetric portrayal of the Arctic Ocean: implications for ocean modeling and geological, geophysical and oceanographic analyses. Geophysical Research Letters 35, L07602. doi:10.1029/ 2008 GL033520.

Jokat, W., Kristoffersen, Y., Rasmussen, T.M., 1992. Lomonosov Ridge - a double sided continental margin. Geology 20, 887-890.

Kaufman, D.S., Polyak, L., Adler, R., Channell, J.E.T., Xuan, C., 2008. Dating late Quaternary planktonic foraminifer Neogloboquadrina pachyderma from the Arctic Ocean using amino acid racemization. Paleoceanography 23, PA3224. doi:10.1029/2008PA001618. 
Knies, J., Gaina, C., 2008. Middle Miocene ice sheet expansion in the Arctic: views from the Barents Sea. Geochemistry, Geophysics, and Geosystems 9, Q02015. doi:10.1029/2007GC001824.

Knies, J., Kleiber, H.-P., Matthiessen, J., Müller, C., Niessen, F., Stein, R., Weiel, D., 2001. Marine ice-rafted debris records constrain maximum extent of Saalian and Weichselian ice-sheets along the northern Eurasian margin. Global and Planetary Change 31, 45-64.

Krylov, A.A., Andreeva, I.A., Vogt, C., Backman, J., Krupskaya, V.V., Grikurov, G.E. Moran, K., Shoji, H., 2008. A shift in heavy and clay mineral provenance indicates a middle Miocene onset of a perennial sea ice cover in the Arctic Ocean. Paleoceanography 23, PA1S06. doi:10.1029/2007PA001497.

Lisiecki, L.E., Raymo, M.E., 2005. A Pliocene-Pleistocene stack of 57 globally distributed benthic $\delta 180$ records. Paleoceanography 20, PA1003. doi:10.1029/2004PA001071.

Löwemark, L., Jakobsson, M., Mörth, M., Backman, J., 2008. Arctic Ocean manganese contents and sediment colour cycles. Polar Research 27, 105-113. doi:10.1111 j.1751-8369.2008.00055.x.

Matthiessen, J., Brinkhuis, H., Poulsen, N., Smelror, M., 2009. Decahedrella martinheadii - a stratigraphic and paleoenvironmental acritarch indicator species for the high northern latitude late Miocene. Micropaleontology 55 (2-3), 171-186.

Miller, K.G., Kominz, M.A., Browning, J.V., Wright, J.D., Mountain, G.S., Katz, M.E. Sugarman, P.J., Cramer, B.S., Christie-Blick, N., Pekar, S.F., 2007. The Phanerozoic record of global sea level change. Science 310, 1293-1298.

Moran, K., et al., 2006. The Cenozoic palaeoenvironment of the Arctic Ocean. Nature $441,601-605$

Myhre, A.M., Thiede, J., Firth, J.V. (Eds). 1995. Proceedings, ODP, Initial Reports, 151, College Station, TX (Ocean Drilling Program).

North Greenland Ice Core Project Members, 2004. High-resolution record of Northern Hemisphere climate extending into the last interglacial period. Nature 431, 147-151. doi:10.1038/nature02805.

O’Regan, M., King, J., Backman, J., Jakobsson, M., Pälike, H., Moran, K., Heil, C., Sakamoto, T., Cronin, T., Jordan, R., 2008a. Constraints on the Pleistocene chronology of sediments from the Lomonosov Ridge. Paleoceanography 23 , PA1S19. doi:10.1029/2007PA001551.

O’Regan, M., King, J., Sakamoto T., 2008b. Regional stratigraphic correlation and a revised composite depth scale for IODP Expedition 302. In Backman, J., Moran, K., McInroy, D.B., Mayer, L.A., and the Expedition 302 Scientists, Proc. IODP, 302 College Station, TX (Integrated Ocean Drilling Program Management International, Inc.). doi:10.2204/iodp.proc.302.202.2008.

Polyak, L., Curry, W.B., Darby, D.A., Bischof, J., Cronin, T.M., 2004. Contrasting glacial/ interglacial regimes in the western Arctic Ocean as exemplified by a sedimentary record from the Mendeleev Ridge. Palaeogeography, Palaeoclimatology, Palaeoecology 203, 73-93.

Richter, T.O., van der Gaast, S., Koster, B., Vaars, A., Gieles, R., de Stigter, H.C., de Haas, H., van Weering, T.C.E., 2006. The Avaatech XRF Core Scanner: technical description and applications to NE Atlantic sediments. In: Rothwell, G. (Ed.) New Techniques in Sediment Core Analysis. Special Publication of the Geological Society, pp. 39-50. 267.

Röhl, U., Abrams, L.J., 2000. High-resolution, downhole and non-destructive core measurements from Sites 999 and 1001 in the Caribbean Sea: application to the Late Paleocene Thermal Maximum. In: Leckie, R.M., Sigurdsson, H., Acton, G.D., Draper, G. (Eds.), Proceedings of the Ocean Drilling Program (ODP), Scientific Results, 165. Ocean Drilling Program, College Station, TX, pp. 191-203.

Rudels, B., Friedrich, H.J., Quadfasel, D., 1999. The Arctic Circumpolar Boundary Current. Deap-Sea Research II 46, 1023-1062.

Rudels, B., Anderson, L., Eriksson, P., Fahrbach, E., Jakobsson, M., Jones, E.P., Melling, H., Prinsenberg, S., Schauer, U., Yao, T., in press. ACSYS chapter 4: Observations in the ocean. In: Lemke, P. (Ed.), ARCTIC climate change - the ACSYS decade and beyond. Springer Verlag, Berlin.
Serreze, M. C., J. A. Maslanik, T. A. Scambos, F. Fetterer, J. Stroeve, K. Knowles, C. Fowler, S. Drobot, R. G. Barry, and T. M. Haran (2003), A record minimum arctic sea ice extent and area in 2002, Geophysical Research Letters, 30(3), 1110. doi: 10.1029/2002GL016406

Sellén, E., Jakobsson, M., Frank, M., Kubik, P.W., 2009. Pleistocene variations of beryllium isotopes in central Arctic Ocean sediment cores. Global and Planetary Change 68 (1-2), 38-47. doi:10.1016/j.gloplacha.2009.03.024

Shimada, K. Carmack, E. Hatakeyama, K. Takizawa, T, 2001. Varieties of shallow temperature maximum waters in the Western Canadian Basin of the Arctic Ocean. Geophysical Research Letters 28, 3441-3444.

Shimada, K., Kamoshida, T., Itoh, M., Nishino, S., Carmack, E., McLaughlin, F., Zimmermann, S., Proshutinsky, A., 2006. Pacific Ocean inflow: influence on catastrophic reduction of sea ice cover in the Arctic Ocean. Geophysical Research Letters 33, LR8605,. doi:10.1029/2005GL025624.

Spiegler, D., 1996. Planktonic foraminifer Cenozoic biostratigraphy of the Arctic Ocean, Fram Strait (Sites 908-909), Yermak Plateau (Sites 910-912), and East Greenland Margin (Site 913). In: Thiede, J., Myhre, A.M., Firth, J.V., Johnson, G.L. Ruddiman, W.F. (Eds.), Proceedings of the Ocean Drilling Program (ODP), Scientific Results, 151. Ocean Drilling Program, College Station, TX, pp. 153-167. doi:10.2973/odp.proc.sr.151.104.1996.

Spielhagen, R.F., Baumann, K.-H., Erlenkeuser, H., Nowaczyk, N.R., NorgaardPedersen, N., Vogt, C., Weiel, D., 2004. Arctic Ocean deep-sea record of northern Eurasian ice sheet history. Quaternary Science Reviews 23, 1455-1483. doi:10.1016/j.quascirev.2003.12.015.

Spielhagen, R.F., 2005. Sedimentology and age control parameter of core PS2185-6, doi:10.1594/PANGAEA.206406.

St. John, K., 2008. Cenozoic ice-rafting history of the central Arctic Ocean: terrigenous sands on the Lomonosov Ridge. Paleoceanography 23, PA1S05. doi:10.1029/2007PA001483.

Steele, M., Boyd, T., 1998. Retreat of the cold halocline layer in the Arctic Ocean. Journal of Geophysical Research 103 (55), 10,419-10,435.

Svendsen, J.I., Alexanderson, H., Astakhov, V.I., Demidov, I., Dowdeswell, J.A. Funder, S., Gataullin, V., Henriksen, M., Hjort, C., Houmark-Nielsen, M., Hubberten, H.W., Ingolfsson, O., Jakobsson, M., Kjnær, K.H., Larsen, E., Lokrantz, H., Lunkka, J.P., Lysa, A., Mangerud, J., Matiouchkov, A., Murray, A. Moller, P., Niessen, F., Nikolskaya, O., Polyak, L., Saarnisto, M., Siegert, C., Siegert, M.J., Spielhagen, R.F., Stein, R., 2004. Late Quaternary ice sheet history of northern Eurasia. Quaternary Science Reviews 23, 1229-1271. doi:10.1016/ j.quascirev.2003.12.008.

Thiede, J., 1991. The Arctic Ocean record: key to global change. Polarforschung 61, $1-102$.

Torsvik, T.H., Carlos, D., Mosar, J., Cocks, L.R.M., Malme, T.N., 2002. Global reconstructions and North Atlantic paleogeography 440 Ma to recent. In: Eide, E.A. (Ed.), BATLAS-Mid Norway plate reconstruction atlas with global and Atlantic perspectives. Norsk Geologiske Undersøgelser, Trondheim, Norway, pp. 18-39.

Vogt, C., Knies, J., 2008. Sediment dynamics in the Eurasian Arctic Ocean during the last deglaciation - The clay mineral group smectite perspective. Marine Geology 250, 211-222.

Woodgate, R.A., Aagaard, K., 2005. Revising the Bering Strait freshwater flux into the Arctic Ocean. Geophysical Research Letters 32, L02602. doi:10.1029/ 2004 GL021747.

Zachos, J.C., Pagani, M., Sloan, L., Thomas, E., Billups, K., 2001. Trends, rhythms, and aberrations in global climate 65 Ma to Present. Science 292. 686-693.

Zhang, J., Rothrock, D.A., Steele, M., 1998. Warming of the Arctic Ocean by a strengthened Atlantic inflow: model results. Geophysical Research Letters 25 (10), 1745-1748 